\title{
INTERAKSI VIRTUAL REMAJA DI MEDIA SOSIAL
}

\author{
indriantiazhar@gmail.com, meibyzulfikar1@gmail.com, \\ ilham.akbar.ikom@gmail.com, sriyantidewi tasdik@yahoo.co.id
}

\begin{abstract}
The study is titled "Virtual Interaction of Teen on Social Media". The purpose of this study was to find out the meaning of Facebook social media for adolescents as a medium of communication in the virtual world, how teenagers express themselves through social media and show the symbol of virtual interacting contemporary teen-age. The theory in this study is the symbolic interaction with the methodology of virtual ethnography. Techniques of determining informants using snowball technique that is through the recommendation of facebook users among adolescents aged 15-18 Years in Cilegon City. Data collection techniques are done by direct observation, in-depth interviews, and documentation. While virtual ethnographic observations are done online and offline. Online observations of researchers interact with resource persons in social media, offline researchers face to face with sources. Triangulation of sources is used in the technique of data validity. The results of this study's first teenage interpreting Facebook as an entertainment, interaction and media interaction in the virtual world. Second, teenagers can express themselves through the status update activity with slang, upload photos with "contemporary" pose and intensity of interaction by chatting to forget the time, and the dependence of updates in social media facebook. The three virtual interaction symbols of today's teenage views of the many positive comments and negative comments from friends on Facebook on each post.
\end{abstract}

Key Word: Teenagers, , Symbolic Interaction, Virtual Ethnography

\subsection{Latar Belakang Masalah}

Manusia berkomunikasi untuk

berbagi pengetahuan dan

pengalaman. Bentuk umum

komunikasi manusia termasuk bahasa

sinyal, bicara, tulisan, gerakan dan

penyiaran. Melalui komunikasi, sikap

dan perasaan seseorang atau kelompok orang dapat dipahami oleh pihak lain. Akan tetapi. Komunikasi hanya efektif apabila pesan yang disampaikan dapat ditafsirkan sama oleh penerima pesan tersebut. Dalam komunikasi dapat merubah asumsi individu ataupun kelompok, dengan komunikasi juga dapat mempersuasif 
hingga dapat mempersepsi masyarakat. Hal ini disebabkan dengan isi pesan/informasi yang diberikan oleh komunikator ke komunikasi.

Walaupun komunikasi sudah dipelajari sejak lama dan termasuk "barang antik", topik ini menjadi penting khususnya pada abad 20 karena pertumbuhan komuniksai digambarkan sebagai penemuan yang revolusioner, karena adanya peningkatan teknologi komunikasi yang pesat seperti radio, televisi, telepon, handphone dan gadget melalui transmisi sebuah jaringan.

Semakin canggihnya teknologi komunikasi yang berkembang, secara perlahan teknologi lama mulai ditinggalkan. Bagi masyarakat modern, kini kehadiran teknologi komunikasi dianggap sangat penting karena pada saat ini teknologi komunikasi pada masyarakat modern disebut dengan media baru (new media), yaitu suatu alat sebagai sarana komunikasi yang dimana saling berinteraksi, berpendapat, bertukar informasi, mengetahui berita melalui jaringan internet serta informasinya selalu terbaru secara kilat dan juga lebih efisien ringkas memberikan informasi kepada pembaca atau khalayaknya. Jejaring sosial menjadi bagian dari new media karena pada saat ini jejaring sosial sangat diminati seluruh dunia terutama masyarakat Indonesia. Jejaring sosial melalui media sosial adalah salah satu bagian dari media baru, yang fungsinya juga hampir tidak jauh berbeda dengan media baru yakni berinteraksi, bertukar informasi, dan mempublikasikan aktivitas sehariharinya. Sementara manusia selalu mengadakan interaksi. Setiap interaksi mutlak membutuhkan sarana tertentu. Sarana menjadi medium simbolisasi dari apa yang dimaksudkan dalam sebuah interaksi. Pelaku komunikasi tidak hanya berinteraksi dengan objek lain dan objek-objek sosial, mereka juga berkomunikasi dengan diri mereka sendiri. Para pelaku komunikasi melakukan percakapan sendiri sebagai bagian dari proses interaksi.

Media sosial sudah menjadi sarana komunikasi bagi masyarakat dengan teman, sahabat, keluarga dan lainnya. Begitupula dengan kalangan 
remaja yang umumnya sebagai pengguna aktif media sosial dengan menampilkan identitas berbeda dari identitas aslinya. Media sosial seperti Facebook, Twitter, dan Skype merupakan media yang digunakan untuk mempublikasikan konten seperti profil, aktivitas atau bahkan pendapat pengguna juga sebagai media yang memberikan ruang bagi komunikasi dan interaksi dalam jejaring sosial di media siber. Keberadaan media sosial dapat dengan mudah ditemukan di internet. Pengguna dapat memilih media mana yang ingin digunakan sesuai dengan kebutuhannya. Keberadaan media sosial telah menjadi bagian presentasi diri penggunanya. Pengguna media sosial memanfaatkan medium ini sebagai bagian pengungkapan diri, maupun pemikirannya. Salah satunya fasilitas di Facebook yakni "wall" (dinding) pengguna bisa mengungkapkan apa yang sedang disaksikan/dialami, keadaan sekitar dirinya, hingga bagaimana tanggapan terhadap situasi, misal politik saat ini. Facebook juga menyediakan fasilitas group yaitu fasilitas yang mengumpulkan pengguna Facebook yang tertarik atau memiliki kesamaan terhadap suatu konten. Berdasarkan data pengguna facebook pada November tahun 2015 kategori remaja usia 13-19 mencapai 13 Milyar, data tersebut menunjukan facebook salah satu media sosial populer di kalangan remaja (techinasia.com).

Platform Facebook yang dirancang Mark Zukerberg ini menarik dan begitu digandrungi remaja, dimana masa remaja sebagai periode transisi perkembangan antara masa kanak-kanak dengan masa dewasa yang melibatkan perubahan biologis, kognitif dan sosioemosional. Perubahan-perubahan kognitif yang berlangsung selama transisi seringkali memandang dirinya seolah-olah berada di atas pentas, unik dan tak terkalahkan, keinginan lebih banyak meluangkan waktu bersama kawan-kawan sebaya dimana percakapan yang berlangsung dengan kawan-kawan menjadi lebih intim dan mereka lebih membuka diri (John W. Santock, 2007:20-23).

Dari sekian banyak remaja dan media sosial, peneliti memilih remaja yang aktif di media sosial 
facebook yang usianya masuk dalam kategori remaja yaitu 15-18 tahun dan berdomisili di Kota Cilegon, remaja ini melakukan aktivitas update status, upload foto atau upload video berkaitan dengan kegiatan seharihari. Mereka sangat mengikuti perkembangan informasi-informasi melalui Facebook dari segala aspek misalnya pemberitaan perang, isu-isu mengenai pemerintahan, kriminal, lifestyle terkini hingga gosip-gosip artis. Komunikasi virtual yang banyak digunakan oleh remaja karena selain mereka dapat mengakses berbagai informasi yang diinginkan, sebagian besar dari mereka menggunakannya karena cemas dan tidak ingin dikatakan ketinggalan zaman. Artinya, adanya kelompok atau lingkungan sosial di tengah kehidupan remaja bisa mempengaruhi remaja dalam menggunakan internet. Mereka mudah mengikuti hal-hal yang sedang digandrungi remaja lain saat ini.

Selain itu agar tetap berada dalam pergaulan virtual mereka sering mem-posting aktivitasnya dalam bentuk kata-kata di "wall" Facebook di akun pribadinya yang menggambarkan suasana hati dan pikirannya saat itu, meskipun terkadang postingannya menimbulkan situasi tidak menyenangkan dalam lingkungan pertemanan. Remaja juga sering mengupload foto-fotonya berswafoto (selfie) maupun wefie bersama temantemannya dan ini mereka lakukan hampir setiap hari. Hal ini menimbulkan ketergantungan remaja terhadap penggunaan smartphone, terlebih jika sedang menggunakan Hp mereka bisa berjam-jam online di facebook melakukan aktivitas seperti chatting, update status, upload foto atau video, atau hanya membaca timeline teman lain yang ingin mereka ketahui. Bagi mereka dengan mengekspresikan diri melalui facebook adalah kebutuhan untuk berkomunikasi intens dan betapa pentingnya respon teman-teman di postingannya, baik berupa simbol menyukai atau komentar sederhana dengan emoticon yang tersedia di platform Facebook.

Pola berkomunikasi pengguna di dunia maya merupakan bagian dari konstruksi presentasi dirinya dihadapan pengguna lainnya. Ini 
tercermin dari update status ataupun melalui pesan atau simbol yang diunggahnya. Hal tersebut menjadi daya tarik peneliti untuk mengetahui simbol-simbol interaksi dalam bentuk virtual melalui media sosial Facebook sebagai salah satu media sosial dengan mengidentifikasi simbolsimbol dalam aktivitas interaksi remaja.

\subsection{Landasan Teori}

Perspektif interaksi simbolik mengandung dasar pemikiran tentang “makna subjektif" (subjective meaning) dari perilaku manusia, proses sosial, dan pragmatismenya. Dalam pemaparan kualitatif Herbert Blumer yang berasal dari pemikiran G.H Mead bahwa interaksi simbolik didasarkan pada ide-ide tentang individu dan interaksinya dengan masyarakat. Esensi interaksi simbolik adalah suatu aktivitas yang merupakan ciri manusia, yakni komunikasi atau pertukaran simbol yang diberi makna. Perspektif ini menyarankan bahwa perilaku manusia harus dilihat sebagai proses yang memungkinkan manusia membentuk dan mengatur perilaku mereka dengan mempertimbangkan ekspektasi orang lain yang menjadi mitra interaksi mereka. Definisi yang mereka berikan kepada orang lain, situasi, objek bahkan diri mereka sendiri yang menentukan perilaku manusia. Dalam konteks ini, makna dikonstruksikan dalam proses interaksi dan proses tersebut bukanlah suatu medium netral yang memungkinkan kekuatan-kekutan sosial memainkan perannya, melainkan substansi sebenarnya dari organisasi sosial dan kekuatan sosial. (Mulyana, 2002: 68-70)

Menurut teori interaksi simbolik, kehidupan sosial pada dasarnya adalah interaksi manusia yang menggunakan simbol-simbol, mereka tertarik pada cara manusia menggunakan simbol-simbol yang merepresentasikan apa yang mereka maksudkan untuk berkomunikasi dengan sesamnaya dan juga pengaruh yang ditimbulkan dari penafsiran simbol-simbol tersebut terhadap perilaku pihak-pihak yang terlibat dalam interaksi sosial (Sunarto, 2004:4).

Facebook adalah salah satu media dimana orang dapat 
berinteraksi, khususnya remaja. Remaja masa kini sangat mendewakan media sosial karena di dalamnya remaja dapat berinteraksi dengan siapa saja yang mereka inginkan, dari media sosial jugalah remaja belajar simbol-simbol terbukanya kesempatan berteman lebih banyak. Sebagai bentuk interaksi yang disepakati oleh warga media sosial facebook.

Blumer mengungkapkan tiga premis yang mendasari pemikiran interaksi simbolik, yaitu:

1. Manusia bertindak terhadap sesuatu berdasarkan makna-makna yang dia pahami tentang objek

2. Makna tersebut berasal dari interaksi sosial seseorang dengan orang lain

3. Makna-makna tersebut disempurnakan di saat proses interaksi sosial berlangsung

Karya Mead dalam yang amat penting terdapat dalam bukunya mengambil tiga konsep kritis yang saling mempengaruhi satu sama lain membentuk teori interaksi simbolik yaitu mind, self dan society. (Ardianto, 2007:136).

\section{a. Mind (Pikiran)}

Mead mendefinisikan pikiran sebagai sebuah proses percakapan seseorang dengan dirinya sendiri sebagaimana pikiran adalah fenomena sosial. Pikiran muncul dan berkembang dalam proses sosial dan merupakan integral dari proses sosial. Jadi pikiran didefnisikan secara fungsional ketimbang secara substansif. Berfikir menurut Mead adalah suatu proses dimana individu berinteraksi dengan dirinya sendiri menggunakan simbol-simbol bermakna. Dari proses tersebut individu memilih yang mana diantara stimulus yang tertuju kepadanya dan ditanggapi. Simbol juga digunakan dalam proses berfikir subjektif, terutama simbolsimbol bahasa. Hanya saja simbol itu tidak dipakai secara nyata yaitu melalui percakapan internal. (Wirawan, 2014:124).

Melalui konsep mind, peneliti berusaha mengungkap pikiran remaja terhadap media sosial facebook yang sangat akrab dengan kehidupan mereka dan menjadi sebuah gaya hidup yang tidak dapat ditinggalkan. 
b. Self (Diri)

Menurut Mead, self adalah kemampuan untuk menerima diri sendiri sebagai sebuah objek dari perspektif yang berasal dari orang lain atau masyarakat tapi diri juga merupakan kemampuan khusus sebagai subjek. The self juga memungkinkan orang berperan dalam percakapan dengan orang lain karena adanya sharing of simbol. Jadi the self berkaitan dengan proses refleksi diri yang secara umumn disebut sebagai self control atau self monitoring. Melalui refleksi diri itulah menurut Mead individu mampu menyesuaikan dengan keadaan di mana mereka berada, sekaligus menyesuaikan dari makna dan efek tindakan yang mereka lakukan. Dari sudut pandang deminikan orang memandang dirinya sendiri dapat menjadi individu khusus atau menjadi kelompok sosial sebagai suatu kesatuan. Pada penelitian ini remaja sebagai objek yang memiliki perspektif mengenai media sosial facebook selalu berusaha menggambarkan dan menyesuaikan dirinya dengan ikut memposting topik yang banyak di posting orang lain dengan tujuan remaja dapat diterima di lingkungannya.

\section{c. Society}

Dalam konsep teori Herbert Mead tentang interaksionisme simbolik terdapat prinsip prinsip dasar yang dapat disimpulkan sebagai berikut:

a. Manusia dibekali kemampuan berpikir

b. Kemampuan berpikir ditentukan oleh interaksi sosial individu

c. Dalam berinteraksi sosial, manusia belajar memahami simbol-simbol dan maknanya sehingga manusia menggunakan kemampuan berpikirnya

d. Makna dan simbol membuat kemungkinan manusia bertindak dan berinteraksi

e. Saat berinteraksi manusia dapat mengubah arti dan simbol bergantung penafsiran mereka terhadap situasi

f. Manusia mampu memodifikasi perubahan sebagai hasil interaksi 
dengan diri sehingga ada peluang dan pilihan tindakan

g. Pola tindakan dan interaksi saling berkaitan membentuk kelompok bahkan masyarakat.

Dari aktivitas remaja di media sosial facebook berdampak pada bagaimana mereka bertindak dan berinteraksi dengan lingkungan pertemanan di Facebook. Kesimpulan utama dari teori interaksi simbolik adalah tentang terbentuknya kehidupan bermasyarakat melalui proses interaksi dan komunikasi antar individu dan antar kelompok menggunakan simbol-simbol yang dipahami melalui proses belajar. Media sosial khususnya facebook fungsinya sama dengan media sosial lainnya yaitu menjadi sarana komunikasi di dunia virtual dan memperluas pergaulan namun dari media sosial remaja pun belajar mengadaptasi simbol-simbol yang kemudian menjadi hal yang tidak dapat ditinggalkan kebiasankebiasaan yang dilakukan dalam platform facebook. Begitupun remaja dengan usia belianya mengenal dunia maka media sosial adalah sarana komunikasi virtual termudah bagi mereka untuk berinteraksi satu sama lain dan mengenal simbol-simbol yang memudahkan cara bersosialisasi.

\subsection{Metode Penelitian}

Pendekatan penelitian ini adalah kualitatif dengan paradigma penelitian konstruktivis. Metode penelitian menggunakan etnografi virtual, yaitu penelitian etnografi yang dilakukan di dunia virtual dengan melihat realitas atau fenomena di ruang siber. Teknik wawancara dalam metode etnografi virtual dilakukan dua tahap. Tahap pertama dilakukan secara online dimana peneliti berteman dan melakukan wawancara melalui chatting. Tahap kedua dilakukan secara offline dengan melakukan wawancara langsung untuk mencegah bias informasi dan ketidakpastian validasi data (John \& Foss, 34:2014)

Sumber data berasal dari informan dengan teknik penentuan informan snowball yaitu melalui rekomendasi satu informan ke informan lainnya sebagai pengguna facebook di kalangan remaja usia 1518 Tahun yang berdomisili di Kota 
Cilegon. Dengan memilih informan yang dianggap mengetahui informasi dan masalah yang hendak diteliti secara mendalam dan dapat dipercaya untuk menjadi sumber data yang mantap sehingga kemungkinan pilihan informan dapat berkembang sesuai dengan kebutuhan dan kemantapan peneliti dalam memperoleh data. Teknik observasi partisipan dalam etnografi virtual dilakukan dua cara yaitu online dan offline. Cara pertama partisipan secara online peneliti minimal berteman dengan narasumber di media sosial facebook kemudian mengamati penggunaan facebook narasumber yang diteliti, mengikuti update status, foto atau video yang diunggahnya serta apa yang di share di laman facebooknya, sehingga peneliti memahami kehidupan narasumber di dunia virtual. Secara offline pengamatan pada narasumber untuk lebih memahami karakter individunya ketika berada di dunia nyata apakah berkaitan dengan kebiasaan-kebiasaan di dunia maya. Triangulasi sumber digunakan dalam teknik validitas data. Analisis data menggunakan teknik analisis interaktif yakni dengan tahapan sebagai berikut: pengumpulan data, reduksi data, penyajian data, penarikan simpulan dan verifikasinya.

\subsection{Pembahasan Penelitian}

Komunikasi merupakan salah satu hal yang sangat penting dan berperan dalam kehidupan manusia sebagai mahluk sosial tidak bisa lepas dari orang lain sehingga memerlukan komunikasi sebagai penghubung agar manusia dapat memenuhi keinginan atau kebutuhan pribadinya, komunikasi dapat dilakukan langsung yaitu face to face, kemudian berkembang menjadi tak langsung karena dapat menggunakan media sebagai sarana komunikasi jarak jauh baik pesan dalam bentuk suara ataupun teks. Salah satunya penggunaan sosial media facebook di kalangan remaja saat ini, meskipun ada begitu banyak media sosial menjadi alat komunikasi antar pribadi maupun komunitas namun faktanya penggunaan facebook seluruh dunia melebihi 1 milyar pengguna antar benua antar negara sehingga mereka 
dapat berkomunikasi satu sama lain dengan mudah.

Dalam interaksi simbolik konsep manusia bertindak terhadap sesuatu berdasarkan makna yang dipahami tentang objek yang maknanya berasal dari interaksi sosial seseorang dengan orang lain kemudian disempurnakan saat proses interaksi sosial berlangsung yang dikategorikan dalam mind, self and society. Dimana dalam penelitian ini objeknya adalah remaja yang menggunakan media sosial facebook sebagai media berinteraksi secara virtual. Dari hasil penelitian ditemukan remaja di Kota Cilegon yang menggunakan media sosial facebook sebagai media interaksi, sebagai berikut:

1. Makna media sosial facebook bagi remaja

Berfikir menurut Mead adalah suatu proses dimana individu berinteraksi dengan dirinya sendiri mempergunakan simbolsimbol yang bermakna. Melalui proses interaksi dengan diri sendiri itu, individu memilih yang mana diantara stimulus yang tertuju kepadanya itu akan ditanggapinya.

Hasil penelitian menunjukan bahwa remaja Kota Cilegon memaknai media sosial facebook

a) Facebook bagi remaja sebagai hiburan dengan membaca dan mengetahui postingan anggota facebook lainnya terutama teman-teman sekolahnya dengan begitu mereka cukup terhibur mendapat informasi dari postingan teman-teman yang dishare di laman Facebooknya.

b) Para remaja ini juga memanfaatkan media sosial facebook untuk memperbanyak teman. bagi mereka angka pertemanan yang banyak adalah sebuah prestasi dalam bersosialisasi di media sosial facebook, semakin banyak teman makin luas jaringan pertemanannya.

c) Eksis. Melalui media sosial facebook remaja dapat mengekspresikan dirinya dalam bentuk kata-kata maupun foto yang diuploadnya, dengan begitu remaja beranggapan 
dirinya ada dan eksis di media sosial.

2. Ekspresi diri remaja di media sosial facebook. Ekspresi diri remaja termasuk kesadaran subyektif dan dinamika interaksi antar pribadi dimana Mead menyadari bahwa manusia sering terlibat dalam suatu aktivitas yang di dalamnya terkandung konflik dan kontradiksi internal yang mempengaruhi perilaku yang diharapkan. Mereka menyebut "konflik intrapersonal" yang menggambarkan konflik antara nafsu, dorongan dan lain sebagainya dengan keinginan yang terinternalisasi. Teori ini membuktikan bahwa:

a) Update status menggunakan bahasa gaul yang remaja ketahui melalui media sosial facebook, contohnya penggunaan kata restauran cepat saji Mcdonald di eja menggunakan bahasa Inggris menjadi "emcidi" bukan lagi McD (red. Mekdi), kemudian kata seperti CTA yang berarti "cukup tau aja", atau kata "baper" yang artinya "bawa perasaan" sebagai ekspresi reaksi emosional remaja terhadap postingan teman yang tidak disukainya. Kata-kata tersebut merupakan kata-kata yang mereka sebut dengan "kekinian", dimana jika mereka menggunakan kata-kata kekinian merupakan simbol bahwa mereka remaja yang mengikuti perkembangan pergaulan.

b) Upload foto yang sudah diedit menggunakan aplikasi khusus seperti camera360 dan Lemocam yang dapat menangkap gambar swafoto (selfie) dengan hasil gambar yang memuaskan meskipun sangat berbeda dengan wajah aslinya. Sehingga menarik perhatian orang di laman facebooknya. Upload foto bagi remaja haruslah kekinian dengan gesture dan ekspresi wajah "kekinian" seperti foto selfie dengan warna kulit terlihat lebih cerah tanpa cela, kemudian foto wefie bersama teman-teman dengan pose superhero atau foto bertema OOTD (Outfit Of The Day) yang menampilkan style/pakaian remaja saat mereka 
bergaul. Hal ini mensimbolkan remaja mengkomunikasikan "kekiniannya" dari gaya bahasa hingga gaya pakaian melalui dunia virtual yaitu media sosial facebook.

c) Remaja juga banyak menghabiskan waktunya berjamjam online di facebook, aktivitas yang mereka lakukan diantaranya chatting karena di facebook pun tersedia fitur chatting, membaca status-status orang sampai membaca informasi yang berseliweran di laman Facebook. Hal ini menyebabkan remaja lupa waktu hingga menggeser waktu tidurnya karena asyik online. Itu mereka lakukan menjelang waktu istirahat di malam hari. Penggunaan facebook yang berlebihan membuat remaja bergantung dengan handphone nya dan apa yang diposting oleh orang lain, sehingga menimbulkan keinginan untuk posting dan update status yang sedang kekinian.

3. Simbol interaksi virtual kekinian remaja di media sosial facebook amat penting perannya dalam membentuk pikiran dan diri, maka simbol interaksi remaja amat dipengaruhi oleh komentar dari teman-temannya di facebook dari hasil postingannya, baik itu berupa status (kata-kata) dengan mencurahkan isi hatinya tentang apa saja, ataupun posting foto dimana remaja berharap mendapat respon dan komentar dari foto yang di upload. Komentar pun terdapat dua jenis,

a. Komentar positif, seperti mengomentari status teman yang sedang sakit dengan kata-kata "Get well soon", dari komentar baik seperti itu remaja dapat meningkatkan hubungan pertemanannya menjadi lebih baik dan menumbuhkan persahabatan di dunia maya maupun di pergaulan nyata.

b. Komentar negatif biasanya saling sindir karena konflik pertemanan dan konflik pasangan remaja. Biasanya remaja menghadapi dinamika sosial yang menimbulkan konflik di lingkungannya, termasuk di media sosial dan lingkungan nyata. Konflik-konflik yang 
terjadi biasanya karena ada yang tidak menyukai postingannya di facebook berlanjut konflik di lingkungan nyata.

Berawal dari melihat bagaimana realitas media sosial tidak senyata dengan realitas yang sebenarnya, remaja mengadopsi gaya hidupnya melalui postingan orang lain lewat media sosial facebook, melakukan interaksi melalui dunia virtual kemudian menjalaninya. Dari interaksi yang terjadi di dunia maya, remaja juga memahami simbolsimbol, bahasa, gesture hingga percakapan yang merepresentasikan dunianya melalui facebook.

\subsection{Kesimpulan}

Dari pembahasan di atas dapat disimpulkan bahwa:

a. Makna facebook bagi remaja yang pertama sebagai hiburan semata, kedua sebagai ajang pergaulan yang lebih luas, ketiga eksis di media sosial dalam bentuk virtual.

b. Ekspresi diri remaja melalu facebook diantara, update status dengan bahasa gaul (kekinian) yang dipahami oleh remaja seusianya dan dilakukan hampir setiap hari, kemudian upload foto selfie maupun wifie bersama teman-temannya dengan menggunakan aplikasi foto tercanggih agar menghasilkan gambar yang luar biasa dan berbeda dengan aslinya dengan pose "kekinian" yang terakhir, remaja melakukan chatting dengan teman-teman di facebook hingga mengganggu waktu istirahat.

c. Simbol interaksi virtual remaja di media sosial facebook dilihat melalui komentar dari temantemannya di facebook baik itu komentar positif yang meningkatkan pertemanan dan komentar negatif yang menimbulkan konflik diantara pertemanan maupun pasangannya. 


\section{REFERENSI}

Ardianto, Elvinaro. 2007.

Komunikasi Massa Suatu Pengantar.

Simbiosa Rekatama Media. Bandung

Littlejohn, Stephen W. 2014. Teori

Komunikasi. Salemba Humanika.

Jakarta

Maryanto, M Dwi. 2004. Tanda-

tanda Dalam Kehidupan

Kontemporer. Tiara Wacana.

Yogyakarta

Morrsion, George S. 2013.

Komunikasi Multikultural. Pustaka

pelajar. Jakarta

Mulyana, Dedi. 2002. Metodologi

Kualitatif. Rosdakarya. Bandung

Nasrullah, Rulli. 2014. Teori dan

Riset Media Siber. Kencana Prenada

Media Group.

Santock, W. John. 20017. Remaja.

Erlangga. Jakarta

Wirawan, Ida bagus. 2014. Teori-

teori Sosial Dalam Tiga Paradigma

(Fakta Sosial, Definisi Sosial dan

Perilaku Sosial). Kencana. Jakarta 